\title{
Kognitivno-vedenjska terapija otrok in madostnikov z motnjami tikov
}

\author{
Jana Kodrič \\ Pediatrična klinika, Univerzitetni klinični center Ljubljana
}

\begin{abstract}
Povzetek: V članku je predstavljen pregled motenj tikov in empirično utemeljenih kognitivno-vedenjskih tehnik za neposredno zmanjševanje tikov ter učenje učinkovitih strategij spoprijemanja z neugodnimi psihosocialnimi posledicami tikov pri otrocih in mladostnikih. V prvem delu so opisani tiki in motnje tikov, epidemiološki podatki o motnji tikov, potek motnje, pridružene težave in psihosocialne posledice tikov, načini ocenjevanja ter indikacije za zdravljenje. V drugem delu so skladno s kliničnimi smernicami za obravnavo motenj tikov predstavljene kognitivno-vedenjske metode njihovega zdravljenja. Podrobneje so opisane psihoedukacija ter najbolj proučevani in z empiričnimi dokazi podprti vedenjski tehniki, učenje nadomestnega odziva in izpostavljanje s preprečevanjem odziva, ki sta namenjeni neposrednemu zmanjševanju tikov. Navedeni so izsledki empiričnih raziskav, ki potrjujejo njihovo učinkovitost. V članku so predstavljene tudi druge kognitivno-vedenjske tehnike, namenjene spoprijemanju z neugodnimi psihosocialnimi posledicami tikov in pridruženih težav. Članek je sklenjen z opisom zahtev za izvedbo učinkovite kognitivnovedenjske terapije pri otrocih in mladostnikih s tiki ter razmišljanjem o načinih, s katerimi bi lahko razširili znanje o specifičnih terapevtskih pristopih za obravnavo otrok in mladostnikov s tiki med kognitivno-vedenjskimi terapevti v Sloveniji.
\end{abstract}

Ključne besede: motnje tikov, učenje nadomestnega odziva, izpostavljanje s preprečevanjem odziva, kognitivno-vedenjska terapija

\section{Cognitive-behavioural therapy for children and adolescents with tic disorders}

\author{
Jana Kodrič ${ }^{*}$ \\ Division of Paediatrics, University Medical Centre Ljubljana, Slovenia
}

\begin{abstract}
The article provides an overview of tic disorders and empirically supported cognitive-behavioural techniques for treating tics and helping children and adolescents to learn effective coping skills to manage the adverse psychosocial consequences the ticks may produce. The article first defines and describes tics and tic disorders, it presents the epidemiological data, the course of the disorder, its comorbid conditions and the psychosocial consequences of tics, assessment methods and indications for treatment. The second part of the article focuses on the description of cognitive-behavioural treatment methods compliant with the clinical guidelines for the treatment of tic disorders. Psychoeducation and two of the most studied and empirically supported behavioural techniques - habit reversal training and exposure with response prevention - targeting tics directly, are described in more detail. The results of empirical research corroborating the effectiveness of the behavioural treatments of tics are provided. Other cognitivebehavioural techniques aimed at managing adverse psychosocial consequences and co-occurring problems are also presented. Finally, the requirements for effective cognitive-behavioural therapy for children and adolescents with tics are discussed together with ideas for the dissemination of knowledge of specific therapeutic methods among cognitive-behavioural therapists in Slovenia.
\end{abstract}

Keywords: tic disorders, habit reversal training, exposure with response prevention, cognitive-behavioural therapy

\footnotetext{
${ }^{*}$ Naslov/Address: doc. dr. Jana Kodrič, Služba za otroško psihiatrijo, Pediatrična klinika, Univerzitetni klinični center Ljubljana, Bohoričeva 20, 1000 Ljubljana, e-mail: jana.kodric@kclj.si
}

Članek je licenciran pod pogoji Creative Commons Attribution 4.0 International licence. (CC-BY licenca). The article is licensed under a Creative Commons Attribution 4.0 International License (CC-BY license). 


\section{Motnje tikov}

Tiki so nenadni, hitri, nehotni, ponavljajoči se gibi ali glasovi (Cohen, Leckman in Bloch, 2013; World Health Organization [WHO], 2005). So glavni simptom motenj tikov. Po videzu lahko spominjajo na voljne gibe in glasove, saj skoraj vsak gib ali glas lahko postane tik. Od normalnega gibanja se razlikujejo po pretirani izraznosti, pojavljanju zunaj konteksta in neobvladljivosti (Cohen idr., 2013; Ganos, 2016).

Tike razlikujemo in opisujemo glede na njihovo anatomsko lokacijo, število, pogostost, trajanje, jakost in kompleksnost. Preprosti gibalni tiki so kratki gibi, ki vključujejo le enkratno krčenje posamezne skupine mišic (npr. mežikanje, obrazne grimase, sunki glave, skomigi ramen), kompleksni gibalni tiki pa so nenadni gibi, ki vključujejo krčenje več mišičnih skupin, lahko so videti namerni, trajajo dlje časa, gibi so medsebojno koordinirani in jih je pogosto težko razlikovati od kompulzij. Kompleksni gibalni tiki so tudi samopoškodovalna vedenja, ehopraksija (posnemanje gest drugih), palipraksija (posnemanje lastnih gest) in koporpraksija (obscene geste). Preprosti glasovni tiki (zvoki, ki nastanejo s krčenjem dihalnih mišic, mišic grla, ust ali nosa) so npr. posamezni glasovi, smrkanje, cviljenje, kompleksni glasovni tiki pa so zlogi, besede in fraze, nenavadno spreminjanje hitrosti, glasnosti ali ritma govora, eholalija (ponavljanje besed za drugimi), palilalija (ponavljanje besed za sabo), koprolalija (govorjenje obscenih besed ali fraz). Tiki pogosto nastopajo $\mathrm{v}$ serijah, med katerimi so daljša ali krajša obdobja brez tikov. Čez dan in v daljših časovnih obdobjih so značilna nihanja v izrazitosti simptomov tikov. Njihova jakost, kompleksnost in pogostost se sčasoma povečujejo in zmanjšujejo, njihova oblika se spreminja. Tike ljudje lahko za kratek čas zadržijo, pred tikom posamezniki pogosto poročajo o neprijetnih telesnih občutkih, ki jih silijo, da naredijo tik (angl. premonitory urge), po tiku pa poročajo o trenutnem olajšanju (Cohen idr., 2013; Ganos, 2016; Leckman, 2002; Robertson, 2015b).

Pri otrocih so zelo pogosti prehodni tiki (po nekaterih podatkih jih ima tudi do petina otrok), ki trajajo le nekaj tednov ali mesecev (Cohen idr., 2013; Scahill, Specht in Page, 2014). Kadar tiki pri posamezniku nastopijo pred 18. letom, trajajo vsaj eno leto z možnimi vmesnimi zatišnimi obdobji in niso posledica morebitne bolezni ali zlorabe psihoaktivnih snovi, govorimo o motnjah tikov. Pri posameznikih, ki imajo le gibalne ali le glasovne tike, govorimo o kroničnih gibalnih ali kroničnih glasovnih tikih, pri tistih, ki imajo poleg gibalnih tikov vsaj en glasovni tik, četudi ne sočasno, pa govorimo o tourettovem sindromu (TS) ali sindromu Gillesa de la Touretta (American Psychiatric Association [APA], 2013; World Health Organization [WHO], 2005). Motnje tikov so kompleksna razvojnonevrološka motnja, povezana z genetskimi in nevrofiziološkimi dejavniki (Ganos, 2016; Robertson, 2015a), na izraženost tikov pa vplivajo tudi okoljski dejavniki (Conelea in Woods, 2008).

Tiki se navadno pojavijo med 2. in 21. letom, pri večini med 5. in 7. letom (Robertson, 2011). Med prvimi so navadno preprosti tiki oči ali obraza, postopoma pa se širijo po telesu v smeri od zgoraj navzdol in postajajo kompleksnejši. Glasovni tiki navadno nastopijo leto do dve po gibalnih in se razvijajo od preprostih vokalizacij do kompleksnih glasovnih tikov
(Cohen idr., 2013). Navadno so najizrazitejši med 7. in 15. letom (v povprečju med 10. in 12. letom). V mladostništvu izrazitost tikov upada. Pri treh četrtinah oseb s tiki se izrazitost do zgodnje odraslosti pomembno zmanjša in tiki pomembno manj vplivajo na njihovo delovanje (Robertson, 2015b).

Motnje tikov (kronične gibalne tike, kronične glasovne tike in TS) ima približno 1-2 \% otrok (Knight idr., 2012; Scahill idr., 2014; Whittington idr., 2016). V otroštvu so pogostejše kot $\mathrm{v}$ odraslosti, pri dečkih so pogostejše kot pri deklicah in $\mathrm{v}$ skupinah otrok $\mathrm{z}$ razvojnimi motnjami, učnimi, vedenjskimi in čustvenimi težavami so pogostejše kot v splošni populaciji (Knight idr., 2012; Robertson, 2015b). Motnjam tikov so najpogosteje pridružene motnje pozornosti s hiperaktivnostjo (ADHD; $60 \%$ ), anksiozne motnje (40\%), obsesivno-kompulzivne motnje (OKM; $30 \%$ ) in motnje avtističnega spektra(MAS; $20 \%$ ), pogoste pa so tudi depresija, izbruhi jeze, samopoškodovalno vedenje, neobscena socialno neprimerna vedenja, vedenjska motnja, učne težave, motnje spanja, zlorabe psihoaktivnih snovi in osebnostne motnje v odraslosti ter nižja kakovost življenja (Cohen idr., 2013; Eapen, Cavanna in Robertson, 2016; Martino, Ganos in Pringsheim, 2017; Robertson, 2015b; Whittington idr., 2016).

Motnje tikov in pridružene motnje vplivajo na posameznikovo samopodobo, medosebne odnose (družinske odnose, oblikovanje prijateljstev, medvrstniško nasilje ...), posameznikovo delovanje $\mathrm{v}$ šoli, na delovnem mestu in $\mathrm{v}$ širšem okolju ter na kakovost njegovega življenja (Eapen idr., 2016). Nekateri tiki so za posameznika lahko boleči (npr. sunki glave ali vratu), neprijetni pa so tudi telesni občutki pred tiki (Cohen idr., 2013). Največji učinek na posameznikovo samopodobo, družinske in vrstniške odnose imajo tiki navadno med 7. in 12. letom, posebno v obdobjih stopnjevanja gibalnih in glasnih glasovnih tikov (Leckman, 2002). V domačem in šolskem okolju so gibalni in glasovni tiki lahko moteči in obremenjujoči za druge družinske člane, sošolce in učitelje (Robertson, 2011). Bolj kot tiki lahko na posameznikovo psihosocialno delovanje in kakovost življenja vplivajo pridružene motnje (Cohen idr., 2013; Robertson, 2015b).

\section{Ocenjevanje tikov}

Za ocenjevanje tikov (njihove izrazitosti oz. težavnosti) ter njihovega učinka na otrokovo vsakdanje delovanje in kakovost življenja uporabljamo različne načine opazovanja in ocenjevanja (intervjuje, neposredno opazovanje s štetjem tikov in (samo)ocenjevalne lestvice).

Kot zlati standard za ocenjevanje tikov je uveljavljena Yaleska lestvica za oceno izrazitosti tikov (Yale Global Tic Severity Scale - YGTSS; Leckman idr., 1989; neobjavljeni slovenski prevod N. Bolle in J. Kodrič, osebna komunikacija, september 2018). Oblikovana je kot polstrukturirani intervju. Primerna je za spremljanje poteka motnje in ocenjevanje učinkovitosti terapevtskih ukrepov od otroštva do odraslosti. Sestavljena je iz seznama simptomov, lestvice izrazitosti oz. težavnosti simptomov oziroma tikov in lestvice učinka tikov na posameznikovo delovanje. S seznamom tikov opišemo obliko in anatomsko razporeditev posameznikovih tikov v zadnjem tednu. $\mathrm{Na}$ osnovi zbranih podatkov na lestvici izrazitosti 
simptomov ocenimo število, pogostost, jakost, kompleksnost in vpliv tikov na posamezne dnevne dejavnosti. Na koncu ocenimo učinek tikov na posameznikovo vsakodnevno delovanje (Leckman idr., 1989).

Za oceno izrazitosti tikov in njihovega učinka na otrokovo delovanje se uporabljajo tudi samoocenjevalne lestvice, kot npr. The Motor Tic, Obsessions And Compulsions, Vocal Tic Evaluation Survey (MOVES; Gaffney, Sieg in Hellings, 1994), ali ocenjevalne lestvice, s katerimi otrokove tike ocenjujejo starši, npr. The Parent Tic Questionnaire (PTQ; Chang, Himle, Tucker, Woods in Piacentini, 2009).

S samoocenjevalno Lestvico za ocenjevanje kakovosti življenja otrok in mladostnikov s tiki in TS (The Gilles De La Tourette Syndrome - Quality of Life Scale for Children and Adolescents, C\&A-GTS-QOL; Cavanna idr., 2013; Su idr., 2016; neobjavljeni slovenski prevod J. Kodrič, osebna komunikacija, september 2018) ocenjujemo izraženost tikov in morebitnih simptomov obsesivno-kompulzivne motnje ter njihov učinek na otrokovo čustveno, kognitivno in telesno delovanje ter vsakodnevne dejavnosti. Lestvica $C \& A-G T S$ $Q O L$ vključuje tudi vidno-analogno lestvico otrokovega splošnega življenjskega zadovoljstva $\mathrm{z}$ razponom od 0 do 100 (Cavanna idr., 2013; Su idr., 2016).

\section{Zgodovina obravnave motenj tikov}

Do druge polovice 20. stoletja so bile uveljavljene psihoanalitične razlage tikov, ki so tike povezovale $\mathrm{s}$ psihološkimi vzročnimi mehanizmi. Psihoanalitični terapevtski pristopi pri zdravljenju tikov niso učinkoviti (Fründt, Woods in Ganos, 2017). Vedenjski pristopi zdravljenja tikov so se začeli uveljavljati po letu 1960 (McGuire, Rickets idr., 2015). Zdravljenje s tehniko, pri kateri posameznik namenoma hitro ponavlja tike določeno časovno obdobje (massed (negative) practice), s čimer naj bi zmanjšal pogostost tikov, se ni izkazalo kot učinkovito (Verdellen, van de Griendt, Hartmann, Murphy in Group, 2011). Leta 1973 sta Azrin in Nunn opisala postopek odpravljanja »nervoznih navad« in tikov. Domnevala sta, da imajo tiki psihološke vzroke in se razvijejo kot naučeni refleksni odzivi na travmo (Azrin in Nunn, 1973). Predstavila sta tehniko učenje nadomestnega odziva (angl. Habit Reversal Training - HRT), ki je danes ena od najbolj uveljavljenih in dokazano najučinkovitejših terapevtskih tehnik za zmanjševanje tikov (McGuire idr., 2014; Whittington idr., 2016).

\section{Vedenjski model tikov}

Sodobni vedenjski pristopi so utemeljeni na znanstvenih spoznanjih, da imajo tiki nevrobiološko osnovo, vendar na njihovo izraženost vplivajo tudi zunanji in notranji dejavniki (McGuire, Rickets idr., 2015).

Predhodniki tikov so lahko notranji dejavniki (npr. neprijetni telesni občutki, tesnoba, dolgčas, pričakovanje ...) ali zunanji dejavniki (npr. okolje, dejavnost, odzivi ljudi ...). Tiki so izrazitejši v okoliščinah, ki povzročajo večjo čustveno vznemirjenost (npr. stres, tesnoba, zaskrbljenost ...), ob izpostavljenosti neposrednemu opazovanju, ob utrujenosti, dolgočasju, družabnih dogodkih, ob začetku šolskega leta ali počitnic. Za tike sta značilni sugestivnost (pojavijo ali stopnjujejo se ob omembi tikov v pogovoru, opazovanju tikov ali glasnem komentiranju tikov) in refleksna odzivnost ob nekaterih dražljajih (npr. učiteljičinemu navodilu, naj bodo otroci tiho, lahko sledi glasovni tik). Tiki so redkejši med spanjem, ob večji sproščenosti, usmerjeni pozornosti na določeno dejavnost (npr. med igranjem glasbenega inštrumenta), telesni dejavnosti, avtomatiziranih dejavnostih ali navadah, prostočasnih dejavnostih, obisku zdravnika ... (Cohen idr., 2013; Conelea in Woods, 2008).

Neprijetni telesni občutki, kot so npr. srbenje, nemir, pritisk, napetost, občutek, da »nekaj ni v redu«, pretirana občutljivost za zunanje dražljaje idr., ki vodijo do tika, se pred tikom stopnjujejo, tik pa prinese njihovo razbremenitev. $\mathrm{O}$ neprijetnih telesnih občutkih poroča večina posameznikov s tiki, čeprav ne pred vsakim posameznim tikom (Ganos, 2016). Otroci poročajo o neprijetnih telesnih občutkih približno tri leta po nastopu tikov, navadno pa jih pred desetim letom teže opišejo (Cohen idr., 2013).

Tikom sledijo posledice, ki lahko povečajo ali zmanjšajo pogostost, jakost ali verjetnost njihovega pojavljanja. Vzdržujejo se po načelu pozitivne krepitve (npr. s pozornostjo in odzivom drugih na tike) ali negativne krepitve ( $z$ razbremenjevanjem neprijetnega telesnega občutka s tikom), medtem ko krepitve zadrževanja tikov zmanjšajo pogostost pojavljanja tikov (Cohen idr., 2013; Conelea in Woods, 2008; Verdellen, van de Grient idr., 2011; Woods, Piacentini idr., 2008).

Vedenjski model tikov temelji na odnosu med neprijetnim telesnim občutkom pred tikom in tikom. S tikom se posameznik razbremeni neprijetnega predhodnega občutka in tiki se vzdržujejo po načelu negativne krepitve. Z vedenjskimi terapevtskimi postopki, ki temeljijo na spreminjanju, nadzorovanju ali preprečevanju tika ob sočasnem neprijetnem občutku, prekinemo povezavo med predhodnim občutkom in tikom (Scahill idr., 2013; Specht idr., 2013; Verdellen, Keijsers, Cath in Hoogduin, 2004).

\section{Kognitivno-vedenjska obravnava motenj tikov pri otrocih in mladostnikih}

Smernice za obravnavo motenj tikov (Murphy idr., 2013; Steeves idr., 2012; Verdellen, van de Grient idr., 2011) priporočajo, da se obravnava otrok in mladostnikov z motnjami tikov začne s celostno oceno, $v$ kateri poleg podrobne ocene tikov in njihovega učinka na otrokovo ali mladostnikovo psihosocialno delovanje ocenimo tudi obstoj morebitnih pridruženih motenj. Čeprav so tiki pogosto najopaznejši simptom, otroka ali mladostnika lahko bolj ovirajo pridružene motnje, $\mathrm{ki}$ jih moramo $\mathrm{v}$ takih okoliščinah obravnavati prednostno. Kadar pa na njegovo delovanje najbolj vplivajo tiki, je obravnava usmerjena na zmanjšanje težavnosti, pogostosti in učinka samih tikov (Murphy idr., 2013; Whittington idr., 2016). Nadaljujemo psihoedukacijo, ki je lahko pri otrocih z blagimi tiki, pri katerih nadaljnje zdravljenje ni potrebno, samostojni terapevtski ukrep (Ganos, Martino in Pringsheim, 2017; Nussey, Pistrang in Murphy, 2013; Verdellen, van de Grient idr., 2011). 
Kadar so tiki izraženi v zmerni ali hudi stopnji in otroka pomembno ovirajo $\mathrm{v}$ vsakdanjem življenju, nadaljujemo zdravljenje. Le-to je potrebno, kadar so tiki za posameznika boleči, se ob njih lahko poškoduje, ga ovirajo pri vsakodnevnem delovanju ali predstavljajo izvor nelagodja $\mathrm{v}$ medosebnih odnosih, kar posledično lahko vodi k zmanjšanju kakovosti življenja in razvoju anksioznih in/ali razpoloženjskih motenj (Ganos idr., 2017). Vedenjska terapija za motnje tikov je poleg zdravljenja z zdravili prepoznana kot učinkovita metoda zdravljenja, ki jo smernice (Murphy idr., 2013; Steeves idr., 2012; Verdellen, van de Grient idr., 2011) predlagajo kot terapijo prvega izbora. Kognitivno-vedenjska terapija motenj tikov poleg vedenjskih tehnik, namenjenih zmanjšanju simptomov tikov, vključuje tudi druge kognitivne in vedenjske tehnike, ki so namenjene zmanjšanju negativnega učinka tikov na otrokovo psihosocialno delovanje in kakovost življenja ( McGuire, Arnold idr., 2015).

Dejavniki, ki omejujejo učinkovitost vedenjske terapije tikov, so starost otroka, izrazitost tikov in pridružene motnje (Ganos idr., 2017; Steeves idr., 2012). Otroci, mlajši od 10 let, redkeje prepoznavajo neprijetne predhodne občutke in slabše razumejo pomen terapije, otroci z zelo izrazitimi tiki in nezdravljenim ADHD pa se težko osredinijo na posamezne neprijetne občutke in sodelujejo pri terapiji (Ganos idr., 2017; Steeves idr., 2012).

\section{Psihoedukacija}

Psihoedukacija o tikih je namenjena poučitvi staršev in otroka ali mladostnika o motnji. Otroku ali mladostniku in njegovi družini omogoči razumevanje motnje, razjasni morebitna napačna prepričanja o motnji, poveča zavedanje o simptomih in njihovem sprejemanju, zmanjša vpliv simptomov na družinsko dinamiko ter zmanjša stigmo, povezano z motnjo (Ganos idr., 2017; Nussey idr., 2013; Verdellen, van de Grient idr., 2011). Staršem otrok in mladostnikov s tiki omogoči, da svojemu otroku nudijo ustrezno podporo, razbremeni jih občutkov krivde in tesnobe ter pripravi na spoprijemanje $z$ različnimi težavami, s katerimi se bo otrok ali mladostnik $\mathrm{s}$ tiki srečeval v odnosih doma, v šoli in širšem okolju (Ganos idr., 2017; Verdellen, van de Grient idr., 2011). Psihoedukacija pri učiteljih in vrstnikih otroka ali mladostnika s tiki prispeva k pozitivnejšemu odnosu in vedenju do njega (Nussey idr., 2013).

Otroku ali mladostniku in staršem najprej predstavimo značilnosti tikov. Razložimo jim, da so tiki kompleksna nevrobiološka motnja, za katero vzrokov še ne poznamo natančno. Opišemo tike, spreminjanje njihovih oblik in nihanje njihove izrazitosti. Razložimo jim, da otrok lahko tike delno nadzoruje, odvisno od različnih dejavnikov (npr. motivacije), pogosto pa si ne more pomagati, da tika ne bi naredil. Predstavimo jim tudi druge značilnosti, povezane s tiki, kot so neprijetni telesni občutki in sugestibilnost (dovzetnost za tike ob njihovi omembi ali pogledu nanje), ter dejavnike, ki lahko vplivajo na večjo ali manjšo izrazitost tikov. Opišemo motnje in težave, ki so pogosto pridružene tikom. Pogovorimo se o dosedanjih strategijah spoprijemanja $\mathrm{s}$ težavami in predstavimo možnosti zdravljenja. Staršem povemo, kako ravnati z otrokom ali mladostnikom in kako se odzivati na tike. Odzivanje staršev na tike naj bo nekritično, empatično in podporno, pri čemer naj tikov ne zanikajo, hkrati pa naj se nanje ne odzivajo s pretiranimi čustvenimi odzivi. Spodbudimo jih, da se usmerijo na otroka ali mladostnika in ne le na njegove težave, prepoznavajo njegova močna področja, ga spodbujajo pri udejstvovanju na teh področjih in v socialnih stikih (Ganos idr., 2017; Woods, Piacentini idr., 2008)

\section{Učenje nadomestnega odziva}

Učenje nadomestnega odziva (HRT) je večkomponentni terapevtski pristop, ki združuje več terapevtskih tehnik. Temeljne tehnike, usmerjene na zmanjševanje tikov, so učenje samozavedanja tika, učenje nadomestnega odziva in socialna podpora. Postopek HRT je povzet po terapevtskih priročnikih (Verdellen, van de Griendt, Kriens in van Oostrom, 2011; Woods, Piacentini idr., 2008).

Samozavedanje je namenjeno povečevanju posameznikovega zavedanja tika in napovedi tika oziroma neprijetnega telesnega občutka pred tikom. Vključuje natančen opis tika, prepoznave vsakega njegovega dela, prvih znanilcev in okoliščin tika (prostorov, položajev, navzočih ljudi). Z otrokom ali mladostnikom natančno opišemo opazovani tik. Vključimo vse vidike tika, od začetnega predhodnega občutka, prvih gibov mišic ob tiku do konca tika. Kadar otrok ali mladostnik težko opiše tik, si pomagamo $\mathrm{z}$ uporabo ogledala ali kamere. V nadaljevanju med 10- do 15minutnim pogovorom $\mathrm{z}$ otrokom ali mladostnikom o temah, nepovezanih s tikom, vadimo prepoznavo tika, tako da nam otrok ali mladostnik z dvigom prsta pokaže, ko naredi tik. $\mathrm{S}$ tem povečujemo njegovo zavedanje tika med dejavnostmi, ko ni osredinjen na tike. Ob ustrezni prepoznavi tika otroka ali mladostnika pohvalimo, ob zgrešenem tiku pa ga nežno opozorimo nanj. Prepoznavanje tikov lahko poteka kot igra z otrokom ali mladostnikom, v katero lahko vključimo tudi starše (ali drugo podporno osebo), in ga tako učimo ustrezne prepoznave tikov in odzivanja na otrokove ali mladostnikove zaznane ali nezaznane tike. Ko zmore otrok ali mladostnik uspešno prepoznati tik, enako vadimo prepoznavo neprijetnega telesnega občutka pred tikom, prvega premika ali glasu. Kadar med terapevtskim srečanjem otrok ali mladostnik nima tika, katerega prepoznavo želimo vaditi, spodbudimo pojav tika s pogovorom o tikih, z dejavnostjo, pri kateri je verjetnost pojava tika večja, ali pa ga prosimo, da nam tik pokaže. S prepoznavo nadaljujemo, dokler uspešno ne prepozna štirih ali petih tikov ali dokler nismo prepričani, da se jih zaveda.

Nadaljujemo učenje nadomestnega odziva oziroma s tikom nezdružljivega, manj opaznega ali socialno sprejemljivejšega in naravnejšega giba, ki ga lahko otrok ali mladostnik zadrži v vseh položajih vsaj eno minuto ali dokler ne izgine neprijetni telesni občutek. Nadomestni gib za tik iztegovanja roke je lahko npr. pritisk roke ali komolca ob telo, pri mežikanju so nadometni gibi lahko nadzorovano mežikanje ali usmerjanje pogleda na določeno točko, pri obraznih grimasah je nadomestni gib lahko nežen stisk ustnic ipd. Pri glasovnih tikih otroka ali mladostnika najprej naučimo nadzorovanega (trebušnega) dihanja, namesto tika pa mirno 
vdihne ali izdihne (obratno od smeri prehoda zraka pri tiku). Rabo nadomestnega odziva $\mathrm{z}$ otrokom ali mladostnikom vadimo med pogovorom o temah, ki niso povezane s tikom in terapevtskim kontekstom, s čimer povečamo terapevtski učinek na vsakdanje življenje. Za uspešno rabo nadomestnega odziva otroka ali mladostnika pohvalimo, po potrebi pa ga nežno opozorimo na rabo nadomestnega odziva.

Za redno vadbo učenja nadomestnega odziva potrebuje otrok ali mladostnik tudi socialno podporo pomembnih drugih oseb, najpogosteje staršev. Podporno osebo naučimo tehnik samozavedanja tika in nadomestnega odziva, da lahko otroka ali mladostnika spodbuja pri vadbi in pravilni rabi nadomestnega odziva zunaj terapevtskega okolja. Otrokovo ali mladostnikovo prizadevanje za pravilno rabo nadomestnega odziva med terapevtskimi srečanji in zunaj njih (in ne obdobij brez tikov) starši krepijo s pohvalami in nagradami.

Tike obravnavamo na tedenskih terapevtskih srečanjih drugega za drugim, odvisno od tega, kako moteč ali obremenjujoč je za otroka ali mladostnika določen tik. Izbor tika temelji na hierarhičnem seznamu tikov, ki jih je imel otrok ali mladostnik v preteklem tednu. Navadno za obravnavo posameznega tika potrebujemo eno ali dve terapevtski srečanji, celotna obravnava pa navadno obsega 10-11 srečanj Verdellen, Hoogduin idr., 2011; Woods, Piacentini idr., 2008).

Različica HRT celovita vedenjska intervencija za tike (angl. Comprehensive Behavioral Intervention for Tics CBIT) ( Woods, Piacentini idr., 2008) osnovnim tehnikam HRT dodaja še funkcionalno analizo vedenja, sproščanje in psihoedukacijo.

S funkcionalno analizo vedenja (FAV) ocenimo vpliv notranjih in zunanjih dejavnikov, ki vplivajo na večjo ali manjšo izrazitost tikov. Skupaj z otrokom ali mladostnikom in starši ocenimo (z intervjujem ali ocenjevalno shemo za FAV), v katerih okoljih (npr. v šoli, restavraciji, pri gledanju televizije) in ob katerih stanjih (npr. tesnobi, pričakovanju, jezi) so tiki bolj ali manj izraziti in kakšne so posledice povečanja ali zmanjšanja tikov (npr. socialni odziv sorojencev ali sošolcev, besedna podpora družinskih članov, odmor med šolskim delom). FAV naredimo za vsak tik posebej. $\mathrm{Na}$ osnovi FAV skupaj oblikujemo priporočila, namenjena spoprijemanju z dejavniki, ki tike sprožajo ali jim sledijo in vplivajo na izrazitost tikov. Takšna priporočila, usmerjena na dejavnike pred nastopom tikov, so npr. prilagoditve sedežnega reda v razredu, načina podajanja zahtevnih nalog ali možnost sprostitve po prihodu iz šole ali izogibanje odzivu sorojencev, staršev idr. Priporočila, usmerjena na posledice, so npr. izogibanje odzivanju na tike, onemogočanje izogibanja domačim opravilom in šolskim nalogam zaradi tikov idr.

Sproščanje (trebušno dihanje ali postopno mišično sproščanje) je namenjeno zmanjševanju stresa kot dejavnika, ki otežuje zadrževanje tikov (in ne neposrednemu zmanjševanju tikov).

Otrok ali mladostnik ob podpori staršev ali druge podporne osebe doma vadi rabo nadomestnega odziva (15-30 minut 3-4-krat tedensko), strategije, s katerimi vpliva na predhodne dejavnike in posledice in tehnike sproščanja. Beleži se tudi pogostost tikov in njihov učinek na otrokovo življenje.
Otrokovo ali mladostnikovo motivacijo za sodelovanje na terapevtskih srečanjih in izvajanje terapevtskih nalog doma vzdržujemo z oblikovanjem sistema nagrad (npr. s tehniko žetoniranja). Krepimo otrokovo prizadevanje in trud, ne pa zmanjšanja tikov.

Sklepna srečanja so namenjena tudi preprečevanju ponovitve stopnjevanja simptomov. $\mathrm{Z}$ otrokom ali mladostnikom in starši ponovimo, da so tiki kronična motnja, pri kateri so tiki lahko $\mathrm{v}$ določenih obdobjih (npr. večje izpostavljenosti določenim stresorjem) izrazitejši, preverimo, ali zmorejo prepoznavati takšne okoliščine, ter ponovimo naučene terapevtske strategije in njihovo rabo ( Woods, Piacentini idr., 2008).

$\mathrm{V}$ preteklosti uveljavljenih prepričanj, da $\mathrm{z}$ učenjem nadomestnega odziva le nadomestimo stare tike $\mathrm{z}$ novimi, da se med terapijo enega tika drugi poslabšajo in da se $\mathrm{z}$ usmerjanjem pozornosti na tike le-ti stopnjujejo, raziskave ne potrjujejo (Scahill idr., 2013; Verdellen, van de Grient idr., 2011; Woods, Piacentini idr., 2008).

\section{Izpostavljanje s preprečevanjem odziva}

Izpostavljanje s preprečevanjem odziva (angl. Exposure and response prevention - ERP) je učinkovit vedenjski pristop zmanjševanja težav pri obravnavi obsesivno-kompulzivne motnje, pri katerem posameznika učimo zadrževanja ritualiziranih prislilnih dejanj med dejavnostmi, ki povečujejo njegovo tesnobo (Verdellen idr., 2004). Podobno pri obravnavi tikov z ERP otroka ali mladostnika učimo zadrževati tike (preprečevanje odziva) ob sočasnem izpostavljanju postopno naraščajočim neprijetnim telesnim občutkom (izpostavljanje) in s tem prekiniti povezavo med njima, ne da bi ga učili specifičnih strategij zadrževanja tikov (Verdellen, van de Grient idr., 2011). Tehnika je razdeljena $v$ začetno ali učno fazo (navadno prvi dve srečanji) in izvedbo oziroma vajo ERP. V učni fazi, v kateri terapevt otroka ali mladostnika uči zadrževanja tikov ob sočasni izpostavljenosti neprijetnim telesnim občutkom, je poudarek na postopnem podaljševanju časa zadrževanja tikov. V nadaljnjih terapevtskih srečanjih ERP, ko otrok ali mladostnik že zmore zadrževati tike daljši čas, pa je poudarek na zmanjšanju števila tikov in vzdrževanju njihovega zadrževanja $\mathrm{v}$ situacijah postopno naraščajoče izpostavljenosti neprijetnim občutkom. Postopek izvedbe ERP je povzet po terapevtskem priročniku C. Verdelen, J. van de Griendt idr. (2011):

Pred začetkom obravnave se $\mathrm{z}$ otrokom ali mladostnikom in starši dogovorimo za dnevno 15-minutno beleženje pogostosti vseh tikov. Beleženje izvajajo starši (vedno ista oseba) med izbrano dnevno dejavnostjo. S primerjavo tedenskega povprečja števila tikov v 15-minutnem opazovalnem intervalu spremljamo napredek in učinkovitost terapije. Otroku ali mladostniku in staršem s ponazoritvijo primerljivih telesnih izkušenj (npr. občutka srbenja ob piku komarja) predstavimo odnos med neprijetnimi telesnimi občutki in tikom kot načinom njihovega razbremenjevanja.

Začnemo učenje preprečevanja odziva oziroma zadrževanja tikov (vseh naenkrat). Otroku ali mladostniku rečemo, naj zadržuje tike. Med zadrževanjem spodbujamo 
njegovo prizadevanje in merimo čas do prvega tika, ko ustavimo uro. Postopek ponavljamo približno 15 minut. Otroka ali mladostnika spodbujamo $\mathrm{k}$ doseganju novega časovnega rekorda in ga učimo učinkovitejšega zadrževanja tikov. Starši se med vajo na terapevtskem srečanju učijo terapevtske naloge, spodbujanja otroka ter ustreznih odzivov na vztrajanje ali morebitni tik. $Z$ otrokom ali mladostnikom in starši se dogovorimo za obseg in trajanje vadbe doma med enim in drugim terapevtskim srečanjem. Učenje zadrževanja tikov navadno traja dve terapevtski srečanji. Če zmore otrok ali mladostnik že na prvem srečanju tike zadržati za 15 minut ali več, že na naslednjem srečanju preidemo na vaje izpostavljanja.

Pred izpostavljanjem otroka ali mladostnika naučimo ocenjevati subjektivne občutke nelagodja oziroma neprijetne telesne občutke pred tikom. Uporabimo njegove izraze za opisovanje neprijetnih občutkov. Izberemo pet najizrazitejših tikov in otroka $\mathrm{v}$ določenem časovnem intervalu med izpostavljanjem prosimo, da oceni nelagodni občutek. Kot pri vaji zadrževanja otroku ali mladostniku rečemo, naj zadržuje tike. Kadar naredi tik, ure ne ustavljamo, temveč ga spodbudimo, da nadaljuje zadrževanje tikov. Za vztrajanje ga pohvalimo in spodbudimo $\mathrm{k}$ nadaljevanju zadrževanja. Postopoma otroka ali mladostnika ob zadrževanju tikov izpostavljamo novim okoliščinam, v katerih je pričakovati več tikov (npr. pogovor o tikih, dejavnost, pri kateri ima več tikov) in v katerih naraste njegov občutek nelagodja. Skupaj s starši otrok ali mladostnik vadi izpostavljanje in zadrževanje tikov doma.

Otrokovo ali mladostnikovo motivacijo za sodelovanje med terapevtskimi srečanji in vajami doma vzdržujemo $\mathrm{z}$ oblikovanjem sistema nagrajevanja (npr. z žetoniranjem). Njegovo prizadevanje pri zadrževanju vzdržujemo s spodbudami in informiranjem o uspehu in napredku. Napredek beležimo s spremljanjem števila tikov v opazovanih časovnih intervalih.

ERP je bil prvotno zasnovan kot dvourno tedensko srečanje, poznejše raziskave pa so pokazale, da je učinkovitost enournih terapevtskih srečanj primerljiva (van de Griendt, van Dijk, Verdellen in Verbraak, 2018).

Raziskave niso potrdile pogostega prepričanja staršev in otrok ali mladostnikov, da zadrževanje tikov vodi do njihovega stopnjevanja po obdobju zadrževanja (povratnega učinka). Po obdobju zadrževanja tiki navadno ne presegajo povprečnega izhodiščnega števila (Cohen idr., 2013; Specht idr., 2013). Prav tako zadrževanje tikov ne vodi k začetnemu stopnjevanju neprijetnih telesnih občutkov (Specht idr., 2013; Verdellen idr., 2008)

Ob terapevtskih nalogah ERP so starši pogosto zbegani in sprašujejo, ali to pomeni, da otrok ali mladostnik lahko tike vedno zadržuje, če to želi. Večina ljudi lahko tike bolj ali manj zadrži. S starostjo se zmožnost zadrževanja tikov povečuje. Navadno laže zadržijo tike na tistih telesnih delih, kjer je tikov najmanj (Ganos, 2016). Nekateri ljudje tike zadržijo brez posebnega napora in z minimalno samonadzora, pri drugih pa se ob poskusih zadrževanja tikov stopnjujejo neprijetni telesni občutki. Zadrževanje tikov od njih zahteva veliko mentalnega napora, kar lahko zmanjša njihovo učinkovitost pri sočasnih dejavnostih. Tako lahko otrokovo ali mladostnikovo zadrževanje tikov med poukom negativno vpliva na njegovo učno učinkovitost. Zadrževanje tikov je manj učinkovito, kadar je otrok izpostavljen stresorjem, učinkovitejše pa, kadar obdobjem zadrževanja sledi nagrada, ki krepi želeno vedenje (Cohen idr., 2013; Conelea in Woods, 2008).

\section{Učinkovitost vedenjskih terapevtskih tehnik za tike pri otrocih in mladostnikih}

Rezultati raziskav kažejo, da tako HRT kot ERP učinkovito zmanjšujeta pogostost in jakost gibalnih in glasovnih tikov pri otrocih, mladostnikih in odraslih. Večina raziskav je proučevala učinke vedenjskih terapij tikov pri odraslih, pogosteje je bil proučevan HRT (van de Griendt, Verdellen, van Dijk in Verbraak, 2013). V randomizirani nadzorovani raziskavi pri otrocih in mladostnikih so potrdili pomemben učinek desettedenskega terapevtskega programa HRT v primerjavi s podporno/edukacijsko terapijo na število, pogostost, kompleksnost, jakost in učinek tikov (zmanjšanje izrazitosti tikov za $31 \%$ na lestvici simptomov YGTSS), ki je bil opazen tudi šest mesecev po koncu terapije (Piacentini idr., 2010). V raziskavi, v kateri so primerjali učinkovitost HRT in ERP v mešani skupini otrok, mladostnikov in odraslih, je bil učinek obeh tehnik na zmanjšanje tikov primerljiv (Verdellen idr., 2004). Metaanaliza randomiziranih nadzorovanih študij učinkovitosti vedenjske terapije za motnje tikov v mešani skupini otrok, mladostnikov in odraslih je pokazala zmerno do visoko velikost učinka $(0,67-0,94)$ vedenjskih terapij na zmanjšanje tikov, primerljivo ali višjo od rezultatov metaanaliz randomiziranih študij, v katerih so proučevali učinek najpogosteje uporabljenih zdravil za zmanjševanje tikov. Terapevtski učinek vedenjske terapije je bil večji $\mathrm{v}$ študijah, v katerih so sodelovali starejši udeleženci in $\mathrm{v}$ katerih je bilo število terapevtskih srečanj večje, manjši pa, kadar so imeli udeleženci več simptomov ADHD (McGuire idr., 2014). V metaanalizi, ki je vključevala le študije učinkovitosti HRT pri otrocih in mladostnikih, so potrdili zmerno velikost učinka $(0,64)$ vedenjske terapije v primerjavi $\mathrm{s}$ čakalno listo ali podporno terapijo (Whittington idr., 2016). Rezultati raziskave, v katero so bili vključeni otroci, mladostniki in odrasli, kažejo, da je vedenjska terapija (HRT) učinkovita pri zmanjševanju tikov kot samostojna tehnika ali v kombinaciji z zdravljenjem z zdravili (Sukhodolsky idr., 2017). Rezultati raziskav ne potrjujejo, da bi pri uporabi HRT ali ERP obravnavani simptom (tik) nadomestil drugi simptom ali da bi zadrževanju tikov sledil povratni učinek oziroma stopnjevanje tikov po obdobjih njihovega zadrževanja (Specht idr., 2013; Woods, Himle idr., 2008). Vedenjski pristopi za otroke in mladostnike z motnjami tikov, ki temeljijo na učenju novih vedenjskih vzorcev, so varni in nimajo neželenih učinkov (Piacentini idr., 2010; Scahill idr., 2013; Specht idr., 2013). Nekatere študije potrjujejo uporabnost in dolgoročno učinkovitost HRT v skupinah otrok in mladostnikov (Dabrowski idr., 2018; Yates idr., 2016), kot obetavna pa se kaže tudi uporaba vedenjskih telemedicinskih pristopov (Ricketts idr., 2016). 


\section{Uporaba HRT ali ERP}

Oba vedenjska pristopa sta po svoji učinkovitosti primerljiva (Verdellen idr., 2004). Razlikujeta se v načinu izvedbe, saj pri ERP sočasno obravnavamo vse tike, pri HRT pa vsakega posebej. Nekateri avtorji (van de Griendt idr., 2013) priporočajo prednostno rabo ERP, kadar ima otrok veliko različnih tikov ali kadar ima pridružene simptome OKM, HRT pa, kadar ima malo različnih tikov ali kadar tikov med terapevtskimi srečanji ni (van de Griendt idr., 2013). Avtorji evropskih smernic za obravnavo oseb z motnjami tikov (Verdellen, van de Grient idr., 2011) priporočajo ovrednotenje učinka vedenjske terapije po desetih terapevtskih srečanjih. Ob zadovoljivem učinku priporočajo konec terapije, ob delnem učinku nadaljevanje $\mathrm{z}$ izbranim terapevtskim pristopom, ob nezadovoljivem učinku pa menjavo pristopa.

\section{Mehanizmi delovanja vedenjskih terapevtskih pristopov}

Kljub trdnim dokazom o učinkovitosti vedenjskih terapevtskih pristopov nevrobioloških mehanizmov njihovega delovanja še ne razumemo povsem (Scahill idr., 2013). Z obema tehnikama, HRT in ERP, pokušamo prekiniti povezavo med neprijetnimi predhodnimi telesnimi občutki in tiki, ki se vzdržuje po načelu negativne krepitve (Verdellen idr., 2004). Sprva so domnevali, da je pri obeh postopkih terapevtski učinek posledica habituacije na neprijeten občutek pred tikom (Verdellen idr., 2008), vendar nekatere raziskave kažejo, da ni nujno, da se pri zadrževanju tikov zmanjšajo neprijetni telesni občutki oz. da habituacija ni nujna (Specht idr., 2013). Sodobne raziskave se usmerjajo na proučevanje inhibitornega učenja oz. inhibicije vedenjskega odziva (tika) ob neprijetnem telesnem občutku po načelu klasičnega pogojevanja (Specht idr., 2013)

\section{Dopolnilni kognitivno-vedenjski terapevtski ukrepi}

Poleg vedenjskih tehnik (HRT in ERP), namenjenih zmanjšanju tikov, kognitivno-vedenjsko terapevtsko (KVT) obravnavo dopolnjujemo $\mathrm{z}$ drugimi tehnikami (kognitivno restrukturacijo, tehniko reševanja težav, podporo pozitivnemu vedenju idr.), ki samostojno nimajo neposrednega učinka na zmanjšanje tikov. Namenjene so zmanjšanju neugodnih psihosocialnih težav, povezanih s tiki, kot so vedenja izogibanja zaradi tikov, težave pri vključevanju med vrstnike, nizka samopodoba, izbruhi jeze ..., razvoju strategij spoprijemanja z neugodnimi učinki tikov na socialno vključenost, uravnavanje čustev in samopodobo ter izboljšanju kakovosti življenja otrok in mladostnikov s tiki ( McGuire, Arnold idr., 2015).

Negativne učinke tikov na prepričanja otroka ali mladostnika o sebi (npr. prepričanje, da ga zaradi tikov drugi ne sprejemajo ali zavračajo), njegovo čustveno doživljanje (npr. tesnoba v odnosih z vrstniki) in vedenje (npr. izogibanje določenim dejavnostim) razložimo s kognitivno-vedenjskim modelom. S kognitivno restrukturacijo skupaj z otrokom ali mladostnikom prepoznavamo prevladujoče miselne napake, povezane s tiki (npr. katastrofiziranje, črnobelo mišljenje, zanemarjanje pozitivnega ...), ki vodijo do negativnih avtomatskih misli in napačnih prepričanj o sebi, in jih poskušamo nadomestiti $\mathrm{z}$ bolj realističnimi. Kadar ima otrok ali mladostnik zaradi tikov resnične negativne izkušnje ali težave $\mathrm{v}$ medosebnih odnosih, uporabljamo tehniko reševanje težav in druge tehnike, namenjene učenju socialnih spretnosti (Espil in Houghton, 2018).

$\mathrm{V}$ zadnjih letih se pri obravnavi s tiki povezanih psihosocialnih težav in pridruženih motenj (npr. depresije, anksioznosti) pri mladostnikih uporabljajo tudi novejši KVTpristopi, kot sta terapija sprejemanja in predanosti (Franklin, Best, Wilson, Loew in Compton, 2011) in čuječnost (Reese idr., 2015).

\section{Razprava}

Vedenjski terapevtski tehniki, HRT in ERP, sta učinkovita in varna postopka, s katerima dosežemo zmanjšanje tikov in posledično njihovih negativnih učinkov na psihosocialno delovanje otrok in mladostnikov ( McGuire, Rickets idr., 2015; Scahill idr., 2013; Specht idr., 2013). Raziskave ne potrjujejo, da bi uporaba nadomestnega odziva ali zadrževanje tikov povzročala nadomeščanje tika z drugimi simptomi, povečanje neprijetnih telesnih občutkov pred tikom ali povečanje izrazitosti tikov po obdobju zadrževanja ( McGuire, Rickets idr., 2015; Scahill idr., 2013; Specht idr., 2013; Verdellen idr., 2008; Woods, Piacentini idr., 2008). Kljub pomembnemu zmanjšanju tikov pa s HRT ali ERP redko dosežemo popolno remisijo, zato ju je smiselno dopolniti z drugimi kognitivnimi in vedenjskimi tehnikami, ki nimajo neposrednega učinka na tike, ampak so namenjene spoprijemanju in prilagajanju otroka ali mladostnika na življenje $\mathrm{z}$ motnjo, ki je po svoji naravi kronična. Mednje sodijo pridobivanje ustreznih informacij o motnji tikov, življenju $\mathrm{z}$ njo in načinih zdravljenja ter obvladovanja simptomov, spreminjanje neustreznih prepričanj o motnji, njenem vplivu na posameznikovo življenje in njegovo samopodobo, spreminjanje neustreznih vedenjskih vzorcev, ki so posledica motnje, učenje uravnavanja čustvenih stanj, reševanje težav, povezanih z motnjo ali njenimi posledicami idr. (McGuire, Rickets idr., 2015; Storch idr., 2012). Cilj KVT pri otrocih in mladostnikih s tiki ni odpravljanje tikov, temveč učenje njihovega obvladovanja in življenja z njimi.

Kognitvno-vedenjska terapija pri otrocih in mladostnikih s tiki mora biti prilagojena njihovim potrebam. Kadar imajo otroci in mladostniki s tiki tudi pridružene motnje, prednostno obravnavamo tiste težave, ki imajo na njihovo psihosocialno delovanje večji učinek (Ganos idr., 2017; Whittington idr., 2016). Pogosto to niso tiki, ampak simptomi pridruženih motenj (npr. ADHD, OKM, anksioznosti, depresije ...). Zaradi kompleksnosti motnje nekateri otroci in mladostniki s tiki potrebujejo obravnavo pri več strokovnjakih (npr. psihologu, psihiatru, nevrologu) in so zdravljeni tudi z zdravili, ki učinkujejo na tike ali na katero od pridruženih duševnih motenj. Zdravljenje z zdravili in KVT otroka ali mladostnika s tiki lahko potekata sočasno, vendar je v takšnih okoliščinah pomembno medsebojno sodelovanje KVT-terapevta z drugimi strokovnjaki, ki sodelujejo pri zdravljenju (Ganos, 2016; Verdellen, van de Grient idr., 2011). 
Kognitivno-vedenjska terapija otrok in mladostnikov s tiki je odvisna tudi od zmožnosti in izkušenosti terapevtov in jo lahko izvajajo le ustrezno usposobljeni strokovnjaki (Ganos idr., 2017; Scahill idr., 2013). Terapevti, ki izvajajo KVT pri otrocih in mladostnikih s tiki, morajo poleg kognitivnih in vedenjskih tehnik, ki se uporabljajo pri zdravljenju drugih duševnih motenj (npr. anksioznosti, depresije), poznati tudi posebne terapevtske pristope, ki učinkujejo na izraženost simptomov tikov. V KVT-obravnavi, prilagojeni posameznemu otroku ali mladostniku, mora terapevt znati oceniti tike in morebitne pridružene duševne motnje ter oceniti prednostne cilje obravnave. Skladno s potrebami posameznega otroka ali mladostnika mora izbrati in uporabiti ustrezne terapevtske tehnike, namenjene zmanjševanju tikov ali drugih težav, ter potek terapije ustrezno prilagajati. Terapevtske tehnike mora prilagoditi tudi otrokovi razvojni stopnji in morebitnim posebnostim, povezanim s pridruženimi motnjami (npr. motnjo avtističnega spektra) ali drugimi okoliščinami.

Kot po svetu (Ganos idr., 2017; McGuire, Rickets idr., 2015; Scahill idr., 2013) tudi v Sloveniji ni dovolj ustrezno usposobljenih strokovnjakov, ki bi zagotavljali učinkovito KVT-obravnavo otrokom in mladostnikom s tiki. V Sloveniji jo nudijo kognitivno-vedenjski terapevti (psihologi in zdravniki), usposobljeni skladno z zahtevami Evropske zveze za vedenjske in kognitivne terapije (European Association for Behavioural and Cognitive Therapies - EABCT), ki so pridobili dodatna znanja in izkušnje za uporabo posebnih tehnik za obravnavo otrok in mladostnikov s tiki. Strokovnjaki, ki delamo $\mathrm{z}$ otroki in mladostniki s tiki, si prizadevamo za širjenje znanja, spretnosti in izkušenj s področja posebnih terapevtskih tehnik, namenjenih zdravljenju tikov v okviru veljavnega sistema usposabljanja KVT-terapevtov in drugih oblik izobraževanja. S postopnim povečevanjem števila ustrezno usposobljenih strokovnjakov za KVT motenj tikov bi lahko omogočili večjo dostopnost do dokazano učinkovitega zdravljenja večjemu številu otrok in mladostnikov s tiki.

\section{Sklep}

Motnje tikov so nevrobiološka motnja, pri kateri $\mathrm{z}$ vedenjskima tehnikama HRT in ERP dosežemo dolgoročno učinkovito zmanjšanje tikov in njihovega učinka na posameznikovo psihosocialno delovanje in kakovost življenja. Smernice za obravnavo motenj tikov (Murphy idr., 2013; Steeves idr., 2012; Verdellen, van de Grient idr., 2011) ta dva pristopa priporočajo kot terapevtska pristopa prvega izbora pri otrocih, mladostnikih in odraslih. Kljub dokazani učinkovitosti vedenjskih pristopov je popolna remisija tikov redka, otroci in mladostniki s tiki pa imajo pogosto tudi pridružene duševne motnje. Celovit in potrebam posameznega otroka ali mladostnika prilagojen KVT za motnje tikov poleg tehnik, namenjenih zmanjševanju tikov, vključuje tudi druge kognitivne in vedenjske tehnike. Lete so namenjene učinkovitejšemu spoprijemanju otrok in mladostnikov s tiki in pridruženimi težavami, zmanjšanju negativnih psihosocialnih posledic zaradi tikov in zvišanju kakovosti njihovih življenj.

\section{Literatura}

American Psychiatric Association. (2013). Diagnostic and statistical manual of mental disorders (5. izd.). Washington, DC, ZDA: Avtor.

Azrin, N. H. in Nunn, R. G. (1973). Habit-reversal: A method of eliminating nervous habits and tics. Behaviour Research and Therapy, 11(4), 619-628.

Cavanna, A. E., Luoni, C., Selvini, C., Blangiardo, R., Eddy, C. M., Silvestri, P. R., ... in Termine, C. (2013). The Gilles de la Tourette Syndrome-Quality of Life Scale for children and adolescents (C\&A-GTS-QOL): Development and validation of the Italian version. Behavioural Neurology, 27(1), 95-103.

Chang, S., Himle, M. B., Tucker, B. T. P., Woods, D. W. in Piacentini, J. (2009). Initial psychometric properties of a Brief Parent-Report Instrument for assessing Tic Severity in Children with Chronic Tic Disorders. Child \& Family Behavior Therapy, 31(3), 181-191.

Cohen, S. C., Leckman, J. F. in Bloch, M. H. (2013). Clinical assessment of Tourette syndrome and tic disorders. Neuroscience \& Biobehavioral Reviews, 37(6), 997-1007.

Conelea, C. A. in Woods, D. W. (2008). The influence of contextual factors on tic expression in Tourette's syndrome: A review. Journal of Psychosomatic Research, 65(5), 487-496.

Dabrowski, J., King, J., Edwards, K., Yates, R., Heyman, I., Zimmerman-Brenner, S. in Murphy, T. (2018). The longterm effects of group-based psychological interventions for children with Tourette syndrome: A randomized controlled trial. Behavior Therapy, 49(3), 331-343.

Eapen, V., Cavanna, A. E. in Robertson, M. M. (2016). Comorbidities, social impact, and quality of life in Tourette syndrome. Frontiers in Psychiatry, 7, 97.

Espil, F. M. in Houghton, D. C. (2018). Cognitive restructuring about tics. V J. F. McGuire T. Murphy J. Piacentini in E. A. Storch (ur.), The clinician's guide to treatment and management of youth with Tourette syndrome and tic disorders (str. 101-119). London, Združeno kraljestvo: Academic Press.

Franklin, M. E., Best, S. H., Wilson, M. A., Loew, B. in Compton, S. N. (2011). Habit reversal training and acceptance and commitment therapy for Tourette syndrome: A pilot project. Journal of Developmental and Physical Disabilities, 23(1), 49-60.

Fründt, O., Woods, D. in Ganos, C. (2017). Behavioral therapy for Tourette syndrome and chronic tic disorders. Neurology: Clinical Practice, 7(2), 148-156.

Gaffney, G. R., Sieg, K. in Hellings, J. (1994). The MOVES: A self-rating scale for Tourette's syndrome. Journal of Child and Adolescent Psychopharmacology, 4, 269-280.

Ganos, C. (2016). Tics and Tourette's: Update on pathophysiology and tic control. Current Opinion in Neurology, 29(4), 513-518.

Ganos, C., Martino, D. in Pringsheim, T. (2017). Tics in the pediatric population: Pragmatic management. Movement Disorders Clinical Practice, 4(2), 160-172. 
Knight, T., Steeves, T., Day, L., Lowerison, M., Jette, N. in Pringsheim, T. (2012). Prevalence of tic disorders: A systematic review and meta-analysis. Pediatric Neurology, 47(2), 77-90.

Leckman, J. F. (2002). Tourette's syndrome. Lancet, 360(9345), 1577-1586.

Leckman, J. F., Riddle, M. A., Hardin, M. T., Ort, S. I., Swartz, K. L., Stevenson, J. in Cohen, D. J. (1989). The Yale Global Tic Severity Scale: Initial testing of a clinician-rated scale of tic severity. Journal of the American Academy of Child \& Adolescent Psychiatry, 28(4), 566-573.

Martino, D., Ganos, C. in Pringsheim, T. M. (2017). Tourette syndrome and chronic tic disorders: The clinical spectrum beyond tics. International Review of Neurobiology, 134, 1461-1490.

McGuire, J. F., Arnold, E., Park, J. M., Nadeau, J. M., Lewin, A. B., Murphy, T. K. in Storch, E. A. (2015). Living with tics: Reduced impairment and improved quality of life for youth with chronic tic disorders. Psychiatry Research, 225(3), 571-579.

McGuire, J. F., Piacentini, J., Brennan, E. A., Lewin, A. B., Murphy, T. K., Small, B. J. in Storch, E. A. (2014). A meta-analysis of behavior therapy for Tourette syndrome. Journal of Psychiatric Research, 50, 106-112.

McGuire, J. F., Ricketts, E. J., Piacentini, J., Murphy, T. K., Storch, E. A. in Lewin, A. B. (2015). Behavior therapy for tic disorders: An evidenced-based review and new directions for treatment research. Current Developmental Disorders Reports, 2(4), 309-317.

Murphy, T. K., Lewin, A. B., Storch, E. A., Stock, S. in American Academy of Child and Adolescent Psychiatry Committee on Quality Issues (2013). Practice parameter for the assessment and treatment of children and adolescents with tic disorders. Journal of the American Academy of Child \& Adolescent Psychiatry, 52(12), 1341-1359.

Nussey, C., Pistrang, N. in Murphy, T. (2013). How does psychoeducation help? A review of the effects of providing information about Tourette syndrome and attentiondeficit/hyperactivity disorder. Child: Care, Health and Development, 39(5), 617-627.

Piacentini, J., Woods, D. W., Scahill, L., Wilhelm, S., Peterson, A. L., Chang, S., ... Walkup, J. T. (2010). Behavior therapy for children with Tourette disorder: A randomized controlled trial. JAMA, 303(19), 1929-1937.

Reese, H. E., Vallejo, Z., Rasmussen, J., Crowe, K., Rosenfield, E. in Wilhelm, S. (2015). Mindfulness-based stress reduction for Tourette syndrome and Chronic Tic Disorder: A pilot study. Journal of Psychosomatic Research, 78(3), 293-298.

Ricketts, E. J., Goetz, A. R., Capriotti, M. R., Bauer, C. C., Brei, N. G., Himle, M. B. ... Woods, D. W. (2016). A randomized waitlist-controlled pilot trial of voice over Internet protocol-delivered behavior therapy for youth with chronic tic disorders. Journal of Telemedicine and Telecare, 22(3), 153-162.
Robertson, M. M. (2011). Gilles de la Tourette syndrome: The complexities of phenotype and treatment. British Journal of Hospital Medicine, 72(2), 100-107.

Robertson, M. M. (2015a). A personal 35 year perspective on Gilles de la Tourette syndrome: Assessment, investigations, and management. The Lancet Psychiatry, 2(1), 88-104.

Robertson, M. M. (2015b). A personal 35 year perspective on Gilles de la Tourette syndrome: Prevalence, phenomenology, comorbidities, and coexistent psychopathologies. The Lancet Psychiatry, 2(1), 68-87.

Scahill, L., Specht, M. in Page, C. (2014). The prevalence of tic disorders and clinical characteristics in children. Journal of Obsessive-Compulsive and Related Disorders, 3(4), 394-400.

Scahill, L., Woods, D. W., Himle, M. B., Peterson, A. L., Wilhelm, S., Piacentini, J. C., ... Mink, J. W. (2013). Current controversies on the role of behavior therapy in Tourette syndrome. Movement Disorders, 28(9), 1179-1183.

Specht, M. W., Woods, D. W., Nicotra, C. M., Kelly, L. M., Ricketts, E. J., Conelea, C. A., ... Walkup, J. T. (2013). Effects of tic suppression: Ability to suppress, rebound, negative reinforcement, and habituation to the premonitory urge. Behaviour Research and Therapy, 51(1), 24-30.

Steeves, T., McKinlay, B. D., Gorman, D., Billinghurst, L., Day, L., Carroll, A., ... Pringsheim, T. (2012). Canadian guidelines for the evidence-based treatment of tic disorders: Behavioural therapy, deep brain stimulation, and transcranial magnetic stimulation. The Canadian Journal of Psychiatry, 57(3), 144-151.

Storch, E. A., Morgan, J. E., Caporino, N. E., Brauer, L., Lewin, A. B., Piacentini, J. in Murphy, T. K (2012). Psychosocial treatment to improve resilience and reduce impairment in youth with tics: An intervention case series of eight youth. Journal of Cognitive Psychotherapy, 26(1), 57-70.

Su, M. T., McFarlane, F., Cavanna, A. E., Termine, C., Murray, I., Heidemeyer, L., ... Murphy, T. (2016). The English version of the Gilles de la Tourette Syndrome-Quality of Life Scale for Children and Adolescents (C\&A-GTSQOL): A validation study in the United Kingdom. The Journal of Child Neurology, 32(1), 76-83.

Sukhodolsky, D. G., Woods, D. W., Piacentini, J., Wilhelm, S., Peterson, A. L., Katsovich, L., ... Scahill, L. (2017). Moderators and predictors of response to behavior therapy for tics in Tourette syndrome. Neurology, 88(11), 1029-1036.

van de Griendt, J. M., Verdellen, C. W., van Dijk, M. K. in Verbraak, M. J. (2013). Behavioural treatment of tics: Habit reversal and exposure with response prevention. Neuroscience \& Biobehavioral Reviews, 37(6), 1172-1177.

van de Griendt, J. M. T. M., van Dijk, M. K., Verdellen, C. W. J. in Verbraak, M. J. P. M. (2018). The effect of shorter exposure versus prolonged exposure on treatment outcome in Tourette syndrome and chronic tic disorders - an open trial. International Journal of Psychiatry in Clinical Practice, 1-6. 
Verdellen, C., van de Griendt, J., Hartmann, A., Murphy, T. in ESSTS Guidelines Group (2011). European clinical guidelines for Tourette syndrome and other tic disorders: Part III: Behavioural and psychosocial interventions. European Child \& Adolescent Psychiatry, 20(4), 197-207.

Verdellen, C., van de Griendt, J., Kriens, S. in van Oostrom, I. (2011). Tics: Therapist manual \& workbook for children. Amsterdam, Nizozemska: Boom.

Verdellen, C. W., Hoogduin, C. A., Kato, B. S., Keijsers, G. P., Cath, D. C. in Hoijtink, H. B. (2008). Habituation of premonitory sensations during exposure and response prevention treatment in Tourette's syndrome. Behavior Modification, 32(2), 215-227.

Verdellen, C. W., Keijsers, G. P., Cath, D. C. in Hoogduin, C. A. (2004). Exposure with response prevention versus habit reversal in Tourettes's syndrome: A controlled study. Behaviour Research and Therapy, 42(5), 501-511.

Whittington, C., Pennant, M., Kendall, T., Glazebrook, C., Trayner, P., Groom, M., ... Hollis, C. (2016). Practitioner review: Treatments for Tourette syndrome in children and young people: a systematic review. The Journal of Child Psychology and Psychiatry, 57(9), 988-1004.

World Health Organization. (2005). Mednarodna klasifikacija bolezni in sorodnih zdravstvenih problemov za statistične namene: MKB-10: Deseta revizija. Ljubljana, Slovenija: Inštitut za varovanje zdravja Republike Slovenije.

Woods, D. W., Himle, M. B., Miltenberger, R. G., Carr, J. E., Osmon, D. C., Karsten, A. M., ... Bosch, A. (2008). Durability, negative impact, and neuropsychological predictors of tic suppression in children with chronic tic disorder. Journal of Abnormal Child Psychology, 36(2), 237-245.

Woods, D. W., Piacentini, J. C., Chang, S. W., Deckercbach, T., Ginsburg, G. S., Peterson, A. L., ... Wilhelm, S. (2008). Managing Tourette syndrome: A behavioral intervention for children and adults. Oxford, Združeno kraljestvo: Oxford University Press.

Yates, R., Edwards, K., King, J., Luzon, O., Evangeli, M., Stark, D., ... Murphy, T. (2016). Habit reversal training and educational group treatments for children with Tourette syndrome: A preliminary randomised controlled trial. Behaviour Research and Therapy, 80, 43-50. 